\title{
MENINJAU KEMBALI SUMBER LUAR ISLAM DALAM PENAFSIRAN AL-QUR'AN
}

\author{
Yusri Hamzani ${ }^{1}$
}

\begin{abstract}
This article discusses the foreign sources of Islam in the interpretation of the Qur'an. There are two main focuses in this article: (1) source forms outside Islam in the interpretation traditions of the Qur'an; (2) Categorization of foreign sources in interpretation traditions. The two main focuses are analyzed using aldakhīl wa al-'așil theory which emphasizes the researches of sources in the Book of Tafsir. This type of research is a research library consisting of two sources: primary and secondary. After conducting analysis of such data, the author finds that the source from outside Islam consists of isrāiliyāt and Hadith Maudû ' (false), both of which are categorized as al-Dakhìl bi al-manqûl. In addition to these two, there are also data on science and personal opinions that contradict the values of Qur'anic that became the source of interpretation of the Qur'an, these two things are called al-Dakhil bi al-Ra'y. Normatively, the two typhology is included in the category al-Dakhill al-Mazmûm, the sources that can not be justified when used as a reference in the interpretation and category al-Dakhil alMahmûd is a reliable source of interpretation.
\end{abstract}

Keywords: Al-Dakhīl wa Al- 'Așill, Interpretation of the Qur'an and Traditions

\begin{abstract}
Abstrak: Artikel ini membahas tentang sumber luar Islam dalam penafsiran AlQur'an. Ada dua fokus utama dalam artikel ini: (1) bentuk-bentuk sumber di luar Islam dalam tradisi penafsiran Al-Qur'an; (2) kategorisasi sumber luar Islam dalam tradisi penafsiran. Dua fokus utama tersebut dianalisis dengan menggunakan teori al-dakhīl wa al-'așill yang menekankan pada penelitian kembali sumber-sumber dalam kitab tafsir. Jenis penelitian ini adalah penelitian pustaka yang terdiri dari dua sumber: primer dan sekunder. Setelah melakukan analisis data-data tersebut, penulis menemukan bahwa sumber dari luar Islam terdiri dari isrāiliyāt dan hadis maud̂u' (palsu), kedua hal ini dikategorikan sebagai al-dakhīl bi al-manqûl. Selain dua hal tersebut, ada pula data-data sains dan pendapat pribadi yang bertentangan dengan nilai-nilai qur'ani yang menjadi sumber penafsiran Al-Qur'an, dua hal ini dinamakan al-dakhïl bi al-ra'y. Secara normatif, dua tifologi tersebut termasuk dalam kategori al-dakhīl al-mażmûm, sumber-sumber yang tidak dapat dibenarkan sutuhnya ketika dijadikan sebagai referensi dalam penafsiran dankategori al-dakhīl al-mahmûd yaitu sumber penafsiran yang terpercaya.
\end{abstract}

Kata Kunci: Al-Dakhīl wa Al- 'Așill, Penafsiran Al-Qur'an dan Tradisi

\footnotetext{
${ }^{1}$ Dosen Ilmu Al-Qur'an dan Tafsir, Sekolah Tinggi Agama Islam Darul Kamal Nahdlatul Wathan Kembang Kerang, Aikmel, Lombok Timur. Email: yusri231192@gmail.com
} 


\section{A. Pendahuluan}

Al-Qur'an merupakan kitab terakhir dalam agama semitik yang diturunkan kepada Nabi terakhir dari keturunan Nabi Ibrāhīm. Al-Qur'an yang merupakan bagian dari rentetan kitab suci agamasamawi (continues revelations), tentu memiliki keterkaitan dengan kitab samawi yang lain, seperti Taurat dan Injil. AlQur'an sendiri menjelaskan dirinya sebagai mușaddiq dari kitab suci yang diturunkan sebelumnya. Dengan demikian, tidak mengherankan apabila AlQur'an banyak memuat kisah-kisah yang menjelaskan kondisi masa lalu.

Walaupun demikian, Al-Qur'an tidak serta merta dapat disejajarkan dengan dua kitab suci sebelumnya. Pasalnya, dari sisi waktu, bahasa, dan ajaran teologis, Al-Qur'an cukup berbeda dengan dua kitab suci tersebut. Selain itu, menyamakan Al-Qur'an dengan dua kitab sebelumnya juga merupakan tindakan yang "terburu-buru" karena tidak memiliki alasan yang cukup kuat. Lebih-lebih “menyamakan" Al-Qur'an dengan buku-buku yang lain, seperti yang terjadi pada beberapa pemikiran kontemporer dalam Islam. Alasan utama yang dipaparkan oleh pemikir kontemporer tersebut adalah Al-Qur'an turun di tengah-tengah masyarakat yang tidak hampa dengan ruang dan waktu. Dalam konteks ini, pemikiran semacam itu dapat dibenarkan, karena kitab-kitab sebelumnya juga diturunkan kepada masyarakat yang tidak hampa dengan ruang dan waktu. Namun dalam konteks yang berbeda, pendapat semacam itu perlu dikaji kembali dalam ranah keilmuan yang lebih komprehensif.

Dalam dunia penafsiran Al-Qur'an, isu-isu itu juga cukup berkembang. Kesetaraan Al-Qur'an dan kitab-kitab sebelumnya memicu para penafsir untuk mengutif beberapa informasi yang bersumber dari informasi yang tersebar luas di kalangan para Ahl al-Kiāb. Terlebih ketika corak tafsir bi al-ma'śûr cukup berkembang di masa awal penafsiran Al-Qur'an. Dalam perkembangannya, corak tafsir ini direduksi dengan menghilangkan sanad-sanad yang berkaitan dengan otentisitas informasi yang dikutip. Keadaan ini semakain "membingungkan" para penafsir berikutnya, karena tidak dapat memilah sejumlah informasi yang didapatkan. Dengan demikian, tafsir banyak dipalsukan dan sulit dilakukan pelacakan keabsahannya. Bagi penafsir yang tidak bertanggung jawab,merekadengan mudah memanipulasi tafsir Al-Qur'an demi mempertahankan argumentasi golongannya. Mereka tidak ragu-ragu untuk mengatasnamakan Muhammad dalam pendapatnya. ${ }^{2}$ Oleh karena itu, pengaruh dari ambisi pribadi dan paham-paham dari suatu kelompok penafsir bisa mendorong terjadinya penyimpangan tafsir Al-Qur'an.

Maka penting rasanya untuk melihat ulang sumber-sumber penafsiran yang terdapat dalam kitab-kitab tafsir. Dalam kajian tafsir sumber-sumber

${ }^{2}$ Ahmad Mustafa Hadna, Problematika Menafsirkan Al-Qur'an, Semarang: Toha Putra, 1993, hlm. 49. 
penafsiran yang tidak jelas tersebut dinamai dengan al-dakhïlyang terdiri dari hadis-hadis palsu, riwayat isrā̄liyāt yang tidak sesuai dengan kaidah penafsiran, takwil-takwil yang tidak bertendensikan pada sanad yang șaḥịh, dan menyeleweng dari ayat-ayat Al-Qur'an secara hakiki, dalil-dalil yang tidak sesuai dengan kebenaran maknanya dan teofani (syațhāat) ${ }^{3}$ para Sufi dalam penafsiran mereka. ${ }^{4}$

Berdasarkan pemaparan tersebut, penulis tertarik untuk mengkaji kembali isu ini dengan menggunakan teori al-dakhīl wa al-așil.Secara leksikal, alașillmempunyai arti sesuatu yang akar atau asal yang terpercaya dalam objek yang dimasuki. Sedangkan menurut istilah, al-așil adalah tafsir yang berlandaskan kepada Al-Qur'an dan Sunnah, atau pendapat Sahabat dan Tābi'in atau pandangan yang sesuai dengan kaidah Bahasa Arab dan kaidah penafsiran. ${ }^{5}$ Lawan dari kata al-așil ini adalah al-dakhīlyang merupakan șigah mubālagah.Menurut bahasa, kata tersebut bermakna makar, rekayasa, aib, kerusakan, tamu, yang datang dari luar (asing). ${ }^{6}$ Sedangkan menurut al-Aṣfaḥāni, al-dakhladalah "Burung yang masuk di dalam pepohonan yang rimbun, yang dililitkan, dan dikumpulkan jadi satu’'Ibrahīm 'Abd al-Raḥmān Khalīfah mengartikan al-dakhīl sebagai virus atau sesuatu kurang baik yang merasuki tubuh atau akal manusia. ${ }^{7}$ Pengertian tersebut juga merupakan sebuah ungkapan yang menggambarkan kerusakan pada materi yang dimasukinya. Ia juga bisa diartikan sebagai perselisihan atau ketidaksesuaian antara dua unsur. ${ }^{8}$ Selain dua pengertian di atas, 'Ali Mukhaimir juga mengartikannya sebagai unsur asing yang masuk dalam sebuah lingkungan. Unsur tersebut tidak sesuai dengan aturan lingkungan setempat, baik dari tutur kata atau perbuatannya. $^{9}$

Dalam kasus penafsiran, al-dakhīl dapat dimaknai sebagai sumber-sumber penafsiran yang berasal dari luar atau tidak sesuai dengan Al-Qur'an, hadis dan

\footnotetext{
${ }^{3}$ Seperti penafsiran Ibn 'Araby yang dikutip oleh Abdul Mustaqim tentang penafirannya terhadap ayat Al-Qur'an surat Al-Muzammil ayat 8. Ibn 'Araby menafsirkan dengan “... dan ingatlah nama Tuhanmu yang dia adalah kamu sendiri ...” Lihat Abdul Mustaqim, Pergeseran Epistemologi Tafsir(Yogyakarta: Pustaka Pelajar, 2008), 148. Memang keperluan para sufi dalam menafsirkan atau mentakwilkan ayat-ayat mutasyābihāt Al-Qur'an dan juga hadis-hadis yang mengandung ibarat, serta belakangan digunakan untuk memahami ucapan-ucapan syațahăt (teofani) para sufi terkemuka seperti al-Hallāj, Rabī'ah 'Adawiyah, dll. Lihat Abdul Hadi, Tasawuf yang Tertindas: Kajian Hermeneutika (Jakarta: Paramadina, 1992), hlm. 99.

${ }^{4}$ Mịjjah Gālib 'Abd al-Raḥmān, Dirāsah Mauḍ̄'iyyah wa Tatbīqiyyah fi al-Dakhīl, Kairo: Jāmi’ah Al-Azhar, 1998, hlm. 16.

${ }^{5}$ Muḥammad Sa'̄̄d Muḥammad Ațiyyah Aram, al-Sabīl ila Ma'rifat al-Aṣil wa al-Dakhīl fi al-Tafsìr, Mesir: Zaqāziq, 1998, jil. I, hlm. 45.

${ }^{6}$ A. W. Munawwir, Kamus Al-Munawwir, Surabaya: Pustaka Progresif, 1997, hlm. 392-393.

${ }^{7}$ Ibrahīm 'Abd al-Raḥmān Khalīah, al-Dakhīl fi al-Tafsīr, (Kairo: Jāmi'a al-Azhar, tt.), Juz I, hlm.

${ }^{8}$ Al-Ragīb Al-Aṣfaḥani, Al-Mufradāt fi Garāib Al-Qur'ān, Mesir: Musțafa al-Bāb alJālis, 1961, hlm. 166.

9‘Aly Mukhaimir, al-Dakhîl fi al-Tafsir, Kairo: Jami’a al-Azhar, tt., hlm. 15.
} 
pendapat sahabat yang valid. ${ }^{10}$ Abd al-Wahāb Fayāọ memaknai al-dakhīl sebagai penafsiran Al-Qur'an dengan metode dan atau dengan cara yang bukan dari Islam. ${ }^{11}$ Sedangkan Ibrahīm Abd al-Rahmmān Khalīfah mengatakan bahwa aldakhīl adalah penafsiran Al-Qur'an yang tidak memiliki sumber yang jelas dalam Islam, baik itu tafsir yang menggunakan riwayat-riwayat dari hadis daiff (lemah) dan palsu, ataupun menafsirkannya dengan tafsiran yang sesat dari sang penafsir itu sendiri karena lalai atau ada unsur kesengajaan. ${ }^{12}$ Dan peristiwa al-dakhīl ini terjadinya setelah wafatnya Rasul, seumpama hadīs maudu'āt dan isrā 'îliyāt. ${ }^{13}$ Tentunya hal ini disebabkan karena orang-orang Yahudi dan Nasrani sangat akrab dengan kisah-kisah dalam Al-Qur'an. Sehingga untuk menambah keterangan tentang kisah-kisah itu, para penafsirmerasa perlu untuk menambahkan informasi-informasi dari orang-orang Yahudi dan Nasrani.

Kajian tentang tema ini telah banyak mendapatkan perhatian daripara peneliti sebelumnya, beberapa diantaranya adalah penelitian Muhammad Ulinnuha yang berjudul Konsep Al-Ashil dan al-Dakhil Dalam Tafsir Al-Qur'an yang diterbitkan pada tahun 2017. Dalam tulisan tersebut, dia peneliti tentang otentisitas tafsir Al-Qur'an yang merupakan parameter kritik al-dakhil. Parameter utama yang menjadi penentu sumber tafsir Al-Qur'an dikatakan otentik adalah AlQur'an itu sendiri,sunnah, pendapat sahabat dan tabi'in yang valid, bahasa Arab dan ijtihad yang disertai dengan pemaparan data-data objektif. ${ }^{14}$ Selain penelitian Ulinnuha, terdapat penelitian Rofiq Junaidi yang berjudul Al-Ashil wa al-Dakhil fi Tafsir yang diterbitkan tahun 2014. Fokus penelitian ini terletak pada penggunaan riwayat-riwayat israiliyat dalam kitab-kitab tafsir. Penulisnya menempuh kesimpulan bahwa israiliyat dapat digunakan selama riwayat-riwayat tersebut sejalur dengan Al-Qur'an dan hadis. ${ }^{15}$ Perbedaan penelitian ini dengan penelitian sebelumnya adalah lokus pembahasan dan sistematika. Penelitian Ulinnuha membahas panjang lebar tentang al-dakhil dalam bentuk riwayat dan dirayat, namun tidak menyinggung sama sekali tentang tafsir bercorak sains. Sedangkan penelitian Junaidi hanya menyinggung $a$-dakhīldalam bentuk isrāiliyāt.

\section{B. Sumber Penafsiran Al-Qur'an}

10 'Abd al-Wahāb Fayāḍ, al-Dakhīl fì al-Tafsīr Al-Qur'ān Al-Karīm, Mesir: Maṭba'ah Hasan, 1978, hlm. 13.

11 'Abd al-Wahāb Fayāḍ, al-Dakhīl fì al-Tafsīr..., hlm. 14.

${ }^{12} \mathrm{Ibrahīm}$ ‘Abd al-Raḥmān Khalifah, al-Dakhïl fi al-Tafsīr....., hlm. 20-22. hlm. 246.

${ }^{13}$ Afifudin Dimyathi, Ilmu Tafsir, Ushulihi wa Manhajihi, Sidoarjo: Lisan Arabi, 2016,

${ }^{14}$ Lihat selengkapnya, Muhammad Ulinnuha, “Al-Ashil dan al-Dakhil Dalam Tafsir AlQur'an” dalam Jurnal Madania, vol. 21, no. 02 Desember 2017.

${ }^{15}$ Lihat selengkapnya, Rofiq Junaidi, "Al-Ashil wa Dakhil fi Tafsir" dalam Jurnal AlA'raf, vol. XI, no. 2, Juli-Desember 2014. 
Sumber penafsiran Al-Qur'an terdiri dari dalil yang datang dari Islam (al'așill) dan dalil yang datang dari luar Islam (al-dakhīl). Secara garis besar, aldakhīl dibagi atas dua kategori utama, yaitu al-dakhīl bi al-manqūldan al-dakhīl bi $a l-R a$ 'yi.Kategori yang pertama membahas tentang penafsiran yang disandarkan kepada riwayat-riwayat yang tidak jelas asal-usulnya. Sedangkan kategori yang kedua membahasa tentang penafsiran Al-Qur'an yang dilandaskan kepada teoriteori di luar tradisi keagamaan.

\section{Al-Dakhīl bi al-Manqūl}

Menafsirkan Al-Qur'an dengan menggunakan hadis-hadis palsu kemudian mengatasnamakan Rasulullah atau Sahabatnya. Kemudian tafsir Al-Qur'an dengan menggunakan isrāilliyāt yang sangat bertentangan dengan apa yang ada dalam Al-Qur'an dan hadis-hadis yang șaḥihh. Peristiwa semacam ini terjadi pada masa Tabi'in, karena tafsir telah bersifat sektarian dan mulai terkontaminasi oleh kepentingan mazhab tertentu. Di masa ini pula mulai masuknya riwayat-riwayat isrāīliyātyang menurut Abdul Mustaqim dapat membahayakan kemurnian ajaran Islam. $^{16}$

Setidaknya al-dakhīl bi al-manqūlterbagi menjadi dua jenis yaitu:isrāiliyātdan hadīis mauḍūāt.Banyak pengertian yang diajukan untuk istilah ini. Akan tetapi dalam perspektif yang populer dalam studi Al-Qur'an, istilah tersebut digunakan untuk menyebut tradisi dan laporan yang terkait dengan litelatur yang bersumber dari Agama Yahudi, Kristen, Zoroaster dan beberapa cerita rakyat yang beredar di wilayah timur dekat (near eastern). Secara konklusif, dapat dikatan bahwa setiap "elemen asing" yang termuat dalam tafsir Al-Qur'an bisa dikatan isrā̄liyāt. ${ }^{17}$ Ada juga yang menambahkan beberapa atribut polemis sebagai sesuatu materi atau kisah yang disusupkan oleh musuh-musuh Islam, seperti gharāniq ${ }^{18}$ dan cerita lain yang sama sekali tidak memiliki sumber yang valid dan sengaja dibuat-buat. ${ }^{19}$

Untuk mengetahui seberapa jauh isrā̄liyāt merasuki pikiran para penafsir Al-Qur'an, maka perlu untuk disajikan sejarah singkat tentang isrāiliyāt. Secara

\footnotetext{
${ }^{16}$ Abdul Mustaqim, Madzahibut Tafsir, Peta Metodologi Penafsiran Al-Qur'an Periode Klasik Hingga Kontemporer, Yogyakarta: Nun Pustaka, 2003, hlm. 66.

${ }_{17}$ Ismail Al-Bayrak, "Re-Evaluating The Nation Of Israiliyat" dalam D.E.U Ilahiyyat Fakultesi Dergisi, Sayn XIII-XIV, 2001, hlm. 70.

${ }^{18}$ Kisah gharāniq bercerita tentang beberapa ayat-ayat yang berisi tentang pujian Rasul terhadap beberapa berhala. Riwayat ini terdapat dalam kitab tafsir, diantaranya dikutip oleh AlȚabari dari riwayat Sa'īd bin Jubair, bahwa ketika turun ayat "Apakah kalian tidak melihat latta wa al- 'uzza (an-najm: 19)", maka Rasul membacanya, dan kemudian berkata, "itulah burungburung yang utama dan sungguh pertolongannya sangat dinantikan" dan ketika itu Rasulullah bersujud dan diikuti oleh kaum musyrik...., Lihat Ibn Jarīr al-Tabari, Jamì' al-Bayān fi Ta'wīl alQur'ān, Beirūt: Mu'assasah al-Risālah, 2000, Juz. 18, hlm. 664-666.

${ }_{19}$ Muhammad Ḥusein al-Ẓahabi, Israiliyāt fi al-Tafsìr wa al-Hadïs, Kairo: Maktabah wahbiyah, 1990, hlm.14.
} 
historis, isrāiliyāt terbagi dalam beberapa babak sejarah: Pertama, masa Rasulullah. Pada masa ini, isrā̄liyāt dalam pemaknaan sebagai suatu tradisi, laporan atau cerita terkait agama-agama terdahulu, terutama Yahudi dan Nasrani telah ada dan beredar. Dalam hal ini, israiliyātdiidentikkan dengan tradisi ahl al$K i t a \bar{b}$, yang ketika itu digunakan untuk menyebut penganut agama terdahulu, khususnya Yahudi dan Kristiani. Beberapa hadis menjelaskan adanya himbauan, larangan, sampai keringanan Rasul untuk menerima informasi dari ahl al-kitāb. Diantara hadis-hadis tersebut adalah sebagai berikut:

Dari 'Abd Allāh bin Sābit. Ia berkata bahwa 'Umar ra. mendatangi Rasulullah dan berkata: "wahai Rasulullah, sesunguhnya saya bertemu dengan salah seorang saudara dari Bani Quraidzah, ia membawakan beberapa tulisan kitab Taurat, apakah saya harus menunjukannya kepada engakau?. Ia ('Abd Allāh) berkata: seketika wajah Rasulullah menjadi berubah. 'Abd Allāh berkata: aku berkata pada 'Umar: "wahai 'Umar, tidakkah engaku melihat wajah Rasulullah? Lalu 'Umar berkata: aku rela Allah sebagai Tuhanku, Islam sebagai agamaku, dan Muḥammad sebagai Nabiku", maka hilanglah kegelisihan Rasulullah"20

Menurut Ḥusain al-Zahabi, baik dalam Al-Qur'an maupun hadis memang terdapat dalil yang membolehkan dan melarang. Dalam hal ini, sikap terbaik adalah melakukan kompromi terhadap keduanya. Harus diakui bahwa Islam tidak diturunkan dengan ruang yang ahistoris, Islam melanjutkan mata rantai sejarah yang telah lama terjalin sebelumnya. Dengan demikian, banyak ayat Al-Qur'an yang mempersilahkan untuk bertanya kepada ahl al-kitāb terkait beberapa hakikat yang ada pada mereka. ${ }^{21}$ Namun meski demikian, harus juga diakui bahwa agamaagama tersebut telah mengalami 'penyelewengan' sehingga kebolehan untuk bertanya dan merujuk kepada ahl al-kitāb tidak diperbolehkan secara mutlak dalam setiap persoalan. Namun terbatas pada persoalan yang tidak terkena 'penyelewengan' yang dalam hal ini telah terkonfirmasi oleh Al-Qur'an. ${ }^{22}$

Keterangan tersebut menjadi bukti kemesraan para sahabat dengan informasi-informasi di kalngan para ahl al-kitābpada masa kalsik. Beberapa keterangan ini juga menunjukkan bagaimana intesitas tersebut,

Dari 'Abd Allāh bin Salām, dari ayahnya, bahwasanya ia mendatangi Rasulullah saw. dan berkata: "sesungguhnya aku membaca Taurat dan AlQur'an, kemudian Rasulullah saw. bersabda: bacalah ini (Taurat) satu malam dan bacalah ini (Al-Qur'an) di malam selanjutnya. ${ }^{23} \mathrm{Ka}$ 'ab pernah

${ }^{20}$ Ahmad bin Hambal, Musnad Ahmad bin Hambal, Beirūt: Mu'assasah al-Risālah, 1999, juz. 22, hlm. 468 .

${ }^{21}$ Lihat Al-Qur'an Surat Yunus: 93, al-anbiya: 7, al-Zukhrūf 45, al-Isrā' 101, al-Baqarah: $211 \mathrm{~d} 11$

${ }^{22}$ Muhammad Ḥusein al-Žahabi, isrāīliyāt fì al-Tafsīr....., hlm. 41-43.

${ }^{23}$ Muḥammad bin Aḥmad al-Ẓahabi, Taẓirah al-Huffādz, Beirūt: Dār al-Kutub Al'Ilmiah, 1998, hlm. 25. 
berkata: "diantara orang yang tidak membaca Taurat, aku tidak pernah melihat orang yang paling mengerti isinya selain Abu Hurairah."24

Kedua, isrāīliyāt juga merupakan istilah teknis dalam studi Al-Qur'an. Sebagaimana dijelaskan bahwa pada masa Nabi dan Sahabat belum ditemui istilah isrāiliyāt. Meski demikian, israiliyāt dalam sebuah penomena penafsiran AlQur'an yang digunakan oleh sahabat merujuk kepada beberapa ahl al-kitāb yang sudah ada dari dulu. Kitab yang pertama kali menggunakan istilah israiliyātadalah al-Mas'ūdy (w. 345) dalam kitabnya Murūj al-Zahāb. Meskipun demikian, istilah itu tidak digunakan dalam istilah teknis. Setelah itu muncul kitab yang berjudul isrā̄liyātyang dinisbahkan kepada Wahāb bin Munabbih dan kitab Kut al-Qulūb karya Abū Talib al-Makki. ${ }^{25}$

Ketiga, fase kritis terhadap isrāiliyāt. Setelah melewati masa penggunaan istilah isrā̄liyātbaik secara terminologi maupun teknis. Selanjutnya mulai masuk kepada tahap ini. Hal ini bermula sejak Ibnu Taimiyah menjelaskan israiliyātdalam kitabnya Muqaddimah fi Ușūl al-Tafsīr. Kemudian dilanjutkan oleh muridnya Ibnu Kas̀īr dalam tafsirnya Tafsīr Al-Qur'ān al-Aźim. Di dalam kitab tersebut, Ibnu Kas̄īr mempopulerkan tiga kategori Kasīiryang masih dipakai sampai sekarang: (1)isrāīliyātyang diketahui kebenarannya; (2)isrā̄iliyātyang diketahui kebohongannya; (3) isrā̄liyātyang didiamkan (maskūt anhā) tidak dibenarkan dan tidak disalahkan. ${ }^{26}$

Pada Abad ke-19 penolakan secara besar-besaran terhadap isrāiliyāt dilakukan. Hal ini senada dengan gerakan reformasi Islam. Hal ini tentu saja berkaitan dengan pengaruh kritisme historis yang berasal dari Eropa. Beberapa tokoh besar seperti Muhammad 'Abduh, Rasyīd Riḍā, Abū Rayyah dan Bint Syāti' merupakan tokoh utama yang memberikan perhatian terhadap penolakan kisah isrāiliyātpada masa modern. Mereka beranggapan bahwa isrā̄liyāatadalah sebuah materi yang asing dan sangat berbahaya bagi Islam. Hal ini mengingat isinya yang memuat ide-ide yang tidak rasional. ${ }^{27}$ 'Alī Jum'ah menyebutkan bahwasanya tafsir yang banyak 'dirasuki' isrā̄liyātadalah tafsir bi al-ma's̀̄urkarena disebabkan oleh model atau metode penafsiran yang lebih banyak menggunakan periwayatan, karenaSahabat, Tabi'in senantiasa mendengarkan kabar-kabar yang muncul dari ahlal-kitāb baik dari Yahudi maupun Nasrani. Walaupun tidak menutup kemungkinan, model penafsiran lainnya juga bisa dimasukiisrailiyāt dan pemikiran yang tidak dapat dipertanggungjawabkan otentisitasnya, seperti tafsir $b i$ hlm. 23 .

${ }^{24}$ Syams al-Dīn al-Zahabi, Siyār A'lam al-Nubalā, Beirūt: Mu'assasah al-Risālah, t.t.,

${ }^{25}$ Ismail al-Bayrak, Re-Evaluating The Nation Of Israiliyat...., hlm. 83.

${ }^{26}$ Abu al-Fidā' Ismā'īl Ibn Kasīir, Tafsīr Al-Qur'an Al-Azìm, Beirūt: Dār al-Toyyibah, 1999, juz, I, hlm. 31.

${ }^{27}$ Ismail al-Bayrak, Re-Evaluating The Nation Of Israiliyat....., hlm. 87-88. 
al-ra'y ataupun dalam tafsir isyāry, akan tetapi al-dakhīl dalam corak penafsiran tersebut tidak sebanyak tafsir bial-ma'siūr. ${ }^{28}$

Sedangkan hadìsmaud̄ $\bar{u}$ ' adalah hadis yang diada-adakan, dibuat-buat dan dipalsukan atas nama Rasulullah atau atas nama para Sahabat dan Tabi'in. Tapi, jika kata ini disebutkan tanpa ikatan, maka yang dimaksud dengan maudū'āt adalah hadis yang dipalsukan atas nama Nabi. Sedangkan riwayat yang dipalsukan atas selainnya disebut muqayyad. Misalnya dikatakan: dipalsukan atas nama Ibn'Abbās, atau dipalsukan atas nama Mujāhid. ${ }^{29}$ Ada pula yang mengartikan hadīsmaudū' dengan, "hadis yang diciptakan dan dibuat seseorang (pendusta) yang ciptaan ini yang dinisbatkan pada Rasulullah secara paksaan dan dusta, baik sengaja maupun tidak." 30

Sejarah munculnya hadis palsu ini disebabkan oleh beberapa faktor: (1)faktor politik. Perpecahan umat Islam yang diakibakan kepentingan politik yang terjadi pada masa khalifah 'Ali bin Abi Țālib mempunyai pengaruh signifikan terhadap perpecahan masyarakat kedalam beberapa golongan lalumemunculkan hadis palsu. Masing-masing kelompok berusaha mencari dalilnya dalam Al-Qur'an dan hadis untuk mengunggulkan kelompok mereka masing-masing. Jika tidak menemukan dalilnya, maka mereka menggunakan hadis palsu tentang keunggulan seseorang dan kelompoknya. ${ }^{31}(2)$ Musuh Islam. Setelah masyarakat Muslim meruntuhkan dua negara adikuasa:kerajaan Romawi dan Persia. Ajaran Islam tersebar ke segala penjuru dunia, sementara musuhmusuh Islam tidak mampu melawannya secara terang-terangan, maka mereka meracuni Islam dengan memasukkan beberapa hadīsmauḍ ${ }^{, 32}{ }^{32}(3)$ Tukang cerita. Para pendongeng ini berusaha agar dapat memikat para pendengar, oleh sebab itu mereka membuat cerita yang lucu-lucu dan aneh-aneh guna menarik perhatian orang-orang disekitarnya, dengan membuat hadits palsu. ${ }^{33}$ Tukang cerita itu membuat beberapa riwayat yang seolah-olah dari Rasulullah dengan menempelkan sanadnya. Contohnya, mereka menggambarkan surga dengan suatu ilustrasi yang menakjubkan. Rasulullah bersabda, "Barang siapa yang membaca 'Tidak ada Tuhan selain Allah', maka Allah menciptakan dari setiap kata seekor burung yang paruhnya dari emas dan bulunya dari marjan."

Imām Aḥmad bin Hanbal dan Yahya bin Ma'īn bermusyawarah dan berkata: "Demi Allah aku tidak pernah mendengar hadis ini melainkan sekarang

${ }^{28}$ Jum'ah 'Ali Abd al-Qādir, al-Dakhīl fì al-Dirāsah al-Manhājiyah wa al-Namādij alTatbīqiyah, Kairo: al-Azhar Press, 2006, hlm. 123-124.

${ }^{29}$ Muhammad Ibn Muhammad Abū Syaḥbah, Israiliyat Dan Hadits-Hadits Palsu Tafsir Al-Qur'an, Terj. Mujahidin, dkk., Depok: Keira Publishing, 2014, hlm. 5.

${ }^{30}$ Abdul Majid khon, Ulumul Hadist, Jakarta, Amzah, 2009, hlm. 199.

${ }^{31}$ Munzier Suparta,Ilmu Hadist, Jakarta: Rajawali Pers, 2010, hlm. 182.

${ }^{32}$ Munzier Suparta,Ilmu Hadist..., hlm. 183.

${ }^{33}$ Isa Anshori Muta'al, Dkk, Ulumul Hadits, Palembang, Raden Fatah Press, 2005, cet ke-3, hlm. 108 . 
ini."Setelah selesai berkisah, tukang cerita itu dipanggildan ditanya dari mana dia mendapat hadis tersebut? Dia menjawab: Imām Aḥmad bin Hanbal dan Yahya bin Ma'īn." Saya, Yaḥya bin Ma'īn dan Imām Aḥmad bin Hanbal tidak pernah mendengar hadis ini dari Rasulullah. Lantas ia menjawab: Aku mendengar bahwa Yahya bin Ma'în itu bodoh dan aku tidak pernah membuktikannya selain sekarang, Imām Aḥmad meletakkan tangan di atas mukanya dan diperintahkan untuk meninggalkan majlis tersebut, lalu ia berdiri dan pergi. ${ }^{34}$

Contoh-contoh israiliyātdan hadīsmaud̄ ù yang terdapat dalam kitab tafsir adalah tentang kisah Nabi Yusuf. ${ }^{35}$ Terdapat israiliyātdan riwayat-riwayat yang palsu dan dusta. Di antaranya adalah apa yang dikeluarkan oleh Ibn Jarir dalam tafsirnya, as-Suyuthi dalam al-Durr al-Manśur, dan lainnya, tentang firman Allah Swt., "(ingatlah) ketika Yusuf berkata kepada ayahnya, 'Wahai ayahku, sesungguhnya aku bermimpi melihat sebelas bintang, matahari dan bulan. Aku melihat mereka bersujud kepadaku," (Q.S.Yusuf:4).Suyuţy berkata: Said ibn Mansyûr, Azzār, Abû Ya'la, Ibn Jarīr, Ibn Munz̄īr, Ibn Abû Ḥātim, al-'Uqailiy dalam al-Dhu'afā', Abû al-Syaikh, Hākim dan dia menganggap hal tersebut sahih, Ibn Mardawaih, Abu Nu'aim, dan Baihāqy meriwayatkan secara bersama-sama dalam al-Dalā'il dari Jābir ibn Abd Allāh r.a., dia berkata:

Seorang tukang kebun Yahudi datang kepada Nabi Saw. dan berkata, "Wahai Muhammad, beritahukanlah kepadaku tentang bintang-bintang yang dilihat oleh Yusuf a.s. dan bersujud kepadanya. Apakah namanamanya?"Nabi Saw. diam dan tidak menjawabnya dengan suatu pun. Maka Jibril a.s. turun dan memberi tau beliau tentang nama-namanya. Lalu Rasulullah saw. Mengirim utusan untuk memanggil tukang kebun Yahudi tersebut. Beliau berkata, "Apakah kamu akan beriman jika aku memberitahukan kepadamu tentang nama-namanya?'Dia menjawab, "Ya".Nabi saw.berkata, "Haratsan, Thariq, Dzayyal, Dzulkaftan, Qabis, Dannan, Hawadan, Failaq, Mushbih, Sharukh, Furaikh, Dhiya', dan Nur. Yusuf melihatnya di ufuk langit bersujud kepadanya. Kemudian ketika Yususf menceritakannya kepada Ya'qub, dia berkata, 'Ini adalah perkara terpisah-pisah yang dikumpulkan oleh Allah dari jauh'.'Tukang kebun Yahudi itu pun berkata, "Benar, demi Allah, itu adalah nama-namanya."

Abu Syahbah mengomentari, adapun yang tampak bagi saya, ini berasal dari israiliyāt dan di lekatkan kepada Nabi secara dusta. Selain itu, sayidina Yusuf melihat bintang-bintang tersebut dengan bentuknya, bukan dengan namanamanya. Kemudian, apalah peran nama dalam apa yang disimbolkan oleh mimpi tersebut. Poros riwayat ini adalah Hakam ibn Zahir. Para ulama menganggap Hakam $d a ’ i ̂ f$, dan sebagian besar dari mereka meninggalkannya. Aj-jauzajani

\footnotetext{
${ }^{34}$ Abu Usamah, Ilmu-Ilmu Hadits, Jakarta: Darul Ibn Hazm, 2007, hlm. 205.

${ }^{35}$ Muhammad Ibn Muhammad Abu Syahbah, Israiliyat Dan Hadits-Hadits Palsu....., hlm. 300-301.
} 
berkata, "Dia sangat rendah. Dan dia adalah pemilik hadits tentang ketampanan Yusuf."Dalam Mizan al-I'tidal, Zahaby berkata:Ibn Ma'īn berkata, "Dia tidak śiqah."Dalam kesempatan lain, dia berkata, "Dia bukan apa-apa." Bukhari berkata, "Hadisnya munkar."Dalam kesempatan lain dia berkata, "Para ulama meninggalkannya". Dan dia adalah rawi hadis, "Jika kalian melihat Muawiah di atas mimbarku, maka bunuhlah dia".Apakah riwayat orang semacam ini dapat diperhitungkan dalam perkata seperti ini? cukup untuk menunjukkan kerendahannya, perkataan Bukhari tentangnya, "Haditsnya munkar" dan, "Para ulama meninggalkannya".

Penulis mengutip contoh ini dari bukunya Muḥammad ibn Muhammad Abû Syahbah, ${ }^{36}$ dia mengutip penafsiran Zamakhsyari dalam tafsir al-Kasyyāf dan diikuti oleh al-Nasafi dalam tafsirnya, saat menafsirkan firman Allah dalam surat al-A'raf ayat 31, "Wahai anak Adam, pakailah pakaianmu yang bagus pada setiap (memasuki) masjid, makan dan minumlah, tetapi jangan berlebihan, sungguh Allah tidak menyukai orang yang berlebihan'Diceritakan bahwa alRasyid memiliki seorang tabib Nasrani yang cerdas. Dia berkata kepada Ali ibn Husain ibn Waqid, "Di dalam kitab kalian tidak ada ilmu kedokteran sama sekali. Padahal ilmu itu ada dua macam yaitu ilmu agama dan ilmu tubuh."Kemudian Ali berkata kepadanya, "Allah mengumpulkan ilmu kedokteran semuanya dalam setengah ayat dari kitabNya." Tabib bertanya, "Apakah itu?"Ali menjawab, "Firman Allah "makan dan minumlah dan janganlah berlebihan""

Tabib Nasrani itu berkata, "Dan tidak diriwayatkan sesuatu pun dari Rasul kalian tentang kedokteran.”Ali menjawab, "Rasul kami telah mengumpulkan ilmu kedokteran dalam lafadz yang pendek."Tabib kembali bertanya, “Apakah itu?"Ali menjawab, "beliau bersabda 'Lambung adalah sarang penyakit, dan himyah adalah pangkal obat. Berikanlah kepada tubuh kalian apa-apa yang sudah kalian biasakan"'Maka tabib Nasrani itu berkata, "Kitab dan Nabi kalian tidak menyisakan bagi Galinus sedikitpun dari ilmu kedokteran.'Kemudian Muhammad Abû Syahbah memberikan ulasannya mengenai penafsiran Zamakhsyari di atas. Dia mengatakan bahwa Zamakhsyari benar dalam ayat ini, namun dia salah dalam menyebutkan hadis. Sebab, hadis ini bukanlah perkataan Nabi melainkan perkataan Haris ibn Kaldah, seorang tabib Arab (Abû Syahbah mendasari pendapatnya ini dengan mengutip kitab Kasyf al-Khafā' wa Mazil al-Ilbas) maka Abu Syahbah menyimpulkan bahwa Zamakhsyari telah memasukkan hadis palsu dalam penafsirannya terhadap ayat ini. Ini merupakan al-dakhīl karena tidak sesuai dengan al-'așīl. Selanjutnya Abû Syahbah memaparkan hadis yang sesuai untuk menafsirkan ayat di atas. Diantara perkataan Nabi yang tepat adalah "Anak Adam tidak memenuhi bejana yang lebih buruk dari perutnya. Cukuplah bagi

\footnotetext{
${ }^{36}$ Lihat Muhammad Ibn Muhammad Abu Syahbah, Israiliyat Dan Hadits-Hadits...., hlm. 478 .
} 
anak adam beberapa suap (makanan) yang dapat menegakka tulang punggungnya. Dan jika dia harus makan, maka sepertiga (dari perutnya) untuk makanannya, sepertiga untuk minumnya, dan sepertiga untuk nafasnya. "Hadis ini diriwayatkan oleh Tirmiẓi dan dia berkata hadis ini hasan.

\section{Al-Dakhīl bi al-Ra'yi}

Abū Anas Ḥāmid Aḥmad al-Ṭahīr al-Basyuni mengatakan bahwa dakhīl bi al-ra'yi adalah memasukkan pemikiran dalam pembahasan Al-Qur'an dan ketetapannya yang didasari dengan berbagai macam syarat diterima atau tidaknya pemikiran tersebut. Jika pemikiran tersebut tidak dilandasi oleh hawa nafsu dan tidak bertentangan dengan sumber hukum maka pemikiran tersebut dapat diterima, akan tetapi jika bertentangan dengan sumber hukum dan disertai dengan keinginan, tujuan serta hawa nafsu individual maka pemikiran tersebut tidak dapat diterima atau ditolak. ${ }^{37}$

Sementara sejarah yang menjadi penggerak utama lahirnya aldakhïl dalam tataran pemikiran (al-dakhïl fì al-ra'yi) dimulai ketika kaum Muslim terpecah menjadi banyak sekte dan golongan, akibat kekacauan politik yang saat itu terjadi. ${ }^{38}$ Diantara sekte dan gologan tersebut yang terkenal ada lima, yaitu Ahli Sunnah, Mu'tazilah, Syi'ah, Murji'ah, dan Khawarij. Kelompok terkenal lainnya, seperti Jabariyyah, Batiniyyah, Musyabbihah, dan lain-lain sebagian besar berasal dari kelima kelompok utama itu. Pengikut Syi'ah yang banyak menyandarkan periwayatannya kepada 'Ali padahal riwayat itu tidak ada. Hal ini seperti yang dilakukan oleh orang-orang yang 'mencari muka' ketika pemerintahan dinasti 'Abbasiyah yang telah membuat bermacam-macam riwayat padahal Ibn Abbās tidak pernah mengatakan riwayat seperti itu. ${ }^{39}$ Menafsirkan dengan al-ra'y dan ijtihad tanpa berdasarkan Al-Qur'an dan sunnah maka hukumnya haram. Tidak boleh dilakukan sebagaimana firman Allah dalam Q.S. 17: $36{ }^{40}$ Penafsiran dengan menggunakan $a l-r a y^{\prime} y$ itu identik dengan $t a{ }^{\prime} w \bar{\imath} l .{ }^{41}$

\footnotetext{
${ }^{37}$ Abū Anas Hāamid Aḥmad al-Ṭāhir al-Basyuni, al-Israiliyāt wa al-Mauḍ 'āt wa Bida alTafsīr Qadīman wa Hadisan, t.tt: Dār al-Taqwa, 2004, hlm. 97. 132-134.

${ }^{38}$ Yusuf Hasan Abidu, Tafsir Al-Qur'an; Sejarah Tafsīr dan Metode Para Mufassir, hlm.

${ }^{39}$ Hasbi Ash-Shiddiqie, Ilmu-Ilmu Al-qur'an: Media-Media Pokok Dalam Menafsirkan Al-Qur'an, Jakarta: Bulan Bintang, 1987, hlm. 205.

${ }^{40}$ Manna' Al-Khattan, Pembahasan Ilmu Al-Quran, terj. Halimuddin, Jakarta: Rineka Cipta, 1995, jil. II, hlm. 194.

${ }^{41}$ Lafazh $t a$ 'wīl timbul beriringan dengan tafsir, dalam pembahasan tentang Al-Qur'an, di kalangan ahli tafsir. Kedua kata tersebut menunjukkan penjelasan tentang makna suatu lafazh tertentu dan berusaha mengungkap makna di balik lafazh tersebut. "Seseorang menakwilkan suatu ucapan, artinya ia merenungkanya, mengira-ngira, dan menafsirkanya. Lihat Abdul Halim Hasan, Tafsir Al-Ahkam, (Jakarta: Kencana Prenada Media Group, 2006), hlm. 337. Kata ta'wīl diambil dari kata $a u l$, yang bermakna kembali dan berpaling. Ada juga yang mengatakan, diambil dari kata ail yang berarti "memalingkan", yakni: memalingkan ayat dari makna yang zahir kepada sesuatu
} 
Contoh penakwilan di dalam kitab tafsir adalah penafsiran tentang AlQuran surat Al-Rahman ayat 22, "Keluar dari kedua lautan (laut dan sungai) mutiara dan marjan" Quraish Shihab mengutip penafsiran Az-Zarkasyi tentang takwilannya terhadap ayat ini. Dahulu diketahui bahwa mutiara hanya ditemukan di laut saja. Atas dasar itu arti mutiara dan marjan hanya terdapat di laut. Ayat ini dijadikan sebagai contoh dual dalam arti satu. Al-Zarkasyi telah melakukan pengalihan makna dual ke tunggal. Kemudian Quraish shihab berpendapat bahwa ta'wil seperti itu merupakan suatu kekeliruan karena setelah ditemukan oleh ilmuan dan dalam dunia nyata bahwa di sungai pun ditemukan mutiara. ${ }^{42}$ Penafsiran tentang ayat-ayat yang berkaitan tentang alam memang membutuhkan pembenaran dari science. Bisa jadi apa yang dikatakan Zarkasyi memang sesuai dengan tingkat pengetahuan ilmiah pada zamannya, tetapi karena realitas terus berubah dan rumusan science yang terus mengalami evolusi, maka jika sekarang kita melihat penafsiran Zarkasyi tersebut maka akan dikatakan salah karena tidak sesuai dengan realitas sekarang.

\section{Menimbang Kembali Sumber Tafsir Al-Qur'an}

Setidaknya sampai di sini, kita bisa melihat bahwa al-dakhīl sangat kompleks sifatnya dan sangat banyak terdapat dalam kitab-kitab tafsir. Namun, sampai di sini kita bisa melihat bahwa tidak seluruhnya al-dakhïl dalam penafsiran berorientasi negatif, sehingga penulis membagi al-dakhill dari segi fungsinya menjadi dua, yaitu: 1. al-dakhīl al-mazmûm yaitu masuknya riwayatriwayat atau takwil yang merusak atau yang dianggap tidak perlu dalam sebuah penafsiran. Namun konotasi kata "tidak perlu" itupun masih bias madzhab, artinya bisa jadi menurut madzhab Sunni riwayat-riwayat itu tidak perlu, namun madzhab yang lain menganggapnya perlu. Sehingga masalah al-dakhīl ini sangatlah pelik

makna yang dapat diterima olehnya. Lihat M. Hasbi Ash Shiddieqy, Sejarah dan Pengantar Ilmu Al-Qur'an, (Jakarta: Bulan Bintang, 1994), hlm. 181. Pada zaman dauhulu, sebagian ulama merasa puas dengan menyatakan bahwa Allāh a'lam bi murādih (Allah yang mengetahui maksud-Nya). Tetapi, penafsiran ini tidak memuaskan banyak pihak. Karena itu, sedikit demi sedikit sikap seperti itu berubah dan para mufasir akhirnya beralih pandangan dengan jalan menggunakan $t a$ 'wìl. Memang pada awalnya, masa al-salaf al-Awwal enggan menggunakan ta'wīl: memberi arti metaforis bagi teks keagamaan. Misalnya Imam Malik enggan membenarkan seseorang yang berkata “langit menurunkan hujan". Harus diyakini bahwa sesungguhnya yang menurunkan hujan adalah Allah. Keengganan menggunakan ta'wīl ini menurut sebagian ulama salaf menduga bahwa batu adalah mahluk hidup yang berakal, berdasarkan firman Allah dalam Q.S. Al Baqarah: 74, juga ada yang menduga bahwa Allah mengutus Nabi-Nabi pada lebah berdasarkan Q.S. 16: 68. Lihat M. Quraish Shihab, Membumikan Al Qur'an: Fungsi dan Peran Wahyu dalam Kehidupan Masyarakat, (Bandung: Mizan, 1999), hlm. 97. Sedangkan cendikiawan Muslim kontemporer berpendapat bahwa ta'wil adalah memalingkan atau mengganti makna lafadz yang kuat (räjih) kepada makna yang lemah (marjūh) karena adanya dalil yang menyertainya. Lihat Muhammad Ḥusain al-Źahabi, al-Tafsīr wa al-Mufassirūn, Mesir: Maktabah Wahbah, 2000, hlm. 15.

${ }^{42}$ M. Quraish Shihab, Kidah Tafsir: Syarat, Ketentuan, dan Aturan yang Patut Anda Ketahui dalam Memahami al-Qur'an, Tanggerang: Lentera Hati, 2013, hlm. 227. 
dan bias madzhab. 2. al-dakhīl al-maḥmûdyaitu masuknya riwayat riwayat asing yang justru mendukung sebuah penafsiran, seperti di abad modern yang menggunakan berbagai macam pendekatan (multi approaches) untuk memahami Alquran. Seperti yang dilakukan para peneliti Islam yang mereka istilah sebagaiislamicstudies, dalam memahami Islam dan tentu memahami Al-Qur'an sebagai kitab suci yang mengarahkan penganutnya untuk taat kepada hukumhukum yang dikandung dalam Al-Qur'an.

Hal-hal semacam ini, banyak terdapat dalam kitab tafsir yang bercorak ilmi, yaitu tafsir yang mengaitkan ayat-ayat Al-Qur'an dengan teori science. Seperti penafsiran Umar Juoro yang menyandingkan antara teori big bang dengan serangkain ayat Al-Qur'an yang mengungkapkan awal penciptaan. Di awal-awal pembahasannya dia menguraikan tentang teori big bang dengan memaparkan sejarah lengkap pemikiran para ilmuan serta temuannya, mulai dari Albert Einstein sampai Fred Hoyle. Dalam bukunya itu, jelas sekali bahwa Umar Juoro mendekati Al-Qur'an dengan teori-teori sains yang hidup di priode modern ini. ${ }^{43}$ Belum lagi bukunya Wisnu Arya Wardhana yang menulis buku tentang AlQur'an dan Energi Nuklir, Melacak Teori Einstein dalam Al-Qur'an yang mencoba untuk menyandingkan antara teori-teori yang dikemukakan oleh Einstein dan ayat-ayat dalam Al-Qur'an.

Banyak sekali ilmuan-ilmuan Muslim kontemporer menyandingkan atau menafsirkan ayat-ayat Al-Qur'an yang berkaitan dengan alam dengan menggunakan teori sains terkemuka. Selain tokoh-tokoh di atas, terdapat pula tokoh-tokoh semisal, Ahmad Baiquni dengan bukunya Al-Qur'an Ilmu Pengetahuan dan Teknologi, Mochtar Naim dengan bukunya Kompendium Himpunan Ayat-ayat Al-Qur'an yang berkaitan dengan Biologi dan Kedokteran, dalam buku ini hanya disampaikan ayat-ayat yang berkaitan dengan biologi dan kedokteran, tanpa ditafsirkan dengan jelas.

\footnotetext{
${ }^{43}$ Umar Juoro mencoba untuk menyandingkan antara teori science yang paling terkemuka yaitu big bang dengan beberapa ayat Al-Qur'an, hal ini terlihat ketika dia menafsirkan ayat AlQur'an surat Al-Anbiya' ayat 30, "Dan apakah orang-orang kafir tidak mengetahui bahwasanya langit dan bumi keduanya dahulu satu yang padu, kemudian kami pisahkan antara keduanya. Dari air kami jadikan segala sesuatu yang hidup. Maka mengapakah mereka juga tidak beriman" kata ka nata yang berarti keduanya (bumi dan langit) dahulunya. Sedangkan kata ratqan berarti menyatu atau bepadu. Sebagaimana kita ketahui bahwa alam semesta ini berasal dari satu titik yang tidak nampak yang kemudian meledak dengan energi yang sangat dahsyat. Sedangkan kata $f a$ fatqna huma berarti kami pisahkan keduanya. Di sini terjadi kesamaan antara science dan Alquran. Surat ini tergolong Makkiyah yang diturunkan sekitar 14 abad yang lalu. Teori big bang semakin meyakinkan kita akan kebenaran Al-Qur'an. Tuduhan terhadap Al-Qur'an adalah buatan Muhammad terpatahkan dengan sangat meyakinkan. Bagaimana mungkin Muhammad mengetahui awal penciptaan alam semesta ini jika tidak mendapatkan wahyu dari Allah melalui malaikat Jibril. Di sini terlihat Al-Qur'an sejalan dengan science. Jika ilmuan dan kita pada umumnya dapat membuat interaksi yang baik dan benar akan sangat produktif secara ilmiah dan sekaligus memperkuat keimanan kita. Lihat Umar Juoro, Kebenaran Al-Qur'an dalam Sains: Persandingan Wahyu dan Teori Fisika tentang Alam Semesta, t.t. PT Pustaka Cidesindo, 2011, hlm. 14-15.
} 
Hal-hal seperti ini tentu tidak dapat dikatakan sebagai al-dakhīl almaẓmûm karena justru teori-teori sciencemengukuhkan Alquran yang selalu sesuai dengan perkembangan zaman dan tempat. Sehingga penafsiran para ilmuan yang berbasis kepada ilmu pengetahuan lebih layak dikatakan sebagai al-dakhil al-mahmûd yaitu dimasukkannya teori-teori sciencesebagai penguat ayat-ayat AlQur'an yang berbicara masalah ilmu pengetahuan yang akhir-akhir ini menjadi fokus para ilmuan. Inilah bentuk nyata dari jargon Al-qur'ān șālih likulli zamān wa makān, untuk mencegah terjadi stagnasi dalam proses penafsiran maka sudah tentu al-Qur'an harus didekati dengan pendekatan yang paling populer di era dimana Al-Qur'an itu dikaji. Seperti pada era ini yang disebut dengan zaman teknologi, sehingga teori-teori yang terdapat dalam teknologi tersebut perlu diterapkan untuk menafsirkan ayat-ayat Al-Qur'an yang berkaitan.

\section{Kesimpulan}

Sumber penafsiran dalam tradisi tafsir Al-Qur'an terdiri dari riwayatriwayat (al-manqul) dan pemikiran-pemikiran ( $\left.a l-R a^{\prime} y\right)$. dalam kitab tafsir tidak jarang riwayat-riwayat seperti israiliyat dan hadis maudhu'at menjadi referensi dalam menafsirkan ayat Al-Qur'an. Hal ini "merusak" otentisitas dari tafsir yang banyak mengandung riwayat (tafsir bi al-ma'tsur). Sedangkan dalam tafsir yang cenderung menggunakan al-ra'y juga tidak terlepas dari pengaruh kepentingan pribadi atau kelompok. Dua corak tafsir tersebut berpotensi mengandung sumbersumber yang tidak dapat dipertanggung jawabkan sepenuhnya. Namun tidak dapat dihukumi sebelah mata, bahwa kedua jenis tafsir tersebut juga memberikan sumbangsih yang cukup banyak dalam mempertahankan eksistensi nilai qurani di tengah-tengah masyarakat. Sehingga kajian terhadap ad-dakhil tidak hanya bekonotasi negatif. Ada pula al-dakhil dalam konotasi positif seperti tafsir bercorak sains.

\section{DAFTAR PUSTAKA}

'Abd al-Raḥmān, Miḥjah Gālib, Dirāsah Mauḍūiyyah wa Tatbīqiyyah fi alDakhīl, Kairo: Jāmi'ah Al-Azhar, 1998.

Abū Syaḥbah, Muḥammad Ibn Muḥammad,Israiliyat Dan Hadits-Hadits Palsu Tafsir Al-Qur'an, Terj. Mujahidin, dkk., Depok: Keira Publishing, 2014.

al-Așfaḥani, al-Ragīb, Al-Mufradāt fi Garāib Al-Qur'ān, Mesir: Musțafa al-Bāb al-Jālis, 1961.

al-Basyuni, Abū Anas Ḥāmid Aḥmad al-Ṭāhir, al-Israiliyāt wa al-Mauḍ'āt wa Bida al-Tafsīr Qadīman wa Hadisian, tt: Dār al-Taqwa, 2004. 
Al-Bayrak, Ismail, "Re-Evaluating The Nation Of Israiliyat" dalam D.E.U Ilahiyyat Fakultesi Dergisi, Sayn XIII-XIV, 2001.

Al-Khattan, Manna', Pembahasan Ilmu Al-Quran, terj. Halimuddin, Jakarta: Rineka Cipta, 1995.

al-Qādir, Jum'ah 'Ali Abd, al-Dakhīl fì al-Dirāsah al-Manhājiyah wa al-Namādij al-Tatbiqqiyah, Kairo: al-Azhar Press, 2006.

al-Ṭabari, Ibn Jarīr, Jam̄̄' al-Bayān fi Ta'wīl al-Qur'ān, Beirūt: Mu'assasah alRisālah, 2000.

al-Ẓahabi, Muḥammad bin Aḥmad, Taẓirah al-Huffādz, Beirūt: Dār al-Kutub Al'Ilmiah, 1998.

al-Źahabi, Muḥammad Ḥusain, al-Tafsīr wa al-Mufassirūn, Mesir: Maktabah Wahbah, 2000. , Israiliyāt fi al-Tafsīr wa al-Hadīs, Kairo: Maktabah wahbiyah, 1990.

al-Ẓahabi, Syams al-Dīn, Siyār A'lam al-Nubalā, Beirūt: Mu'assasah al-Risālah, t.t.

Ash Shiddieqy, M. Hasbi, Sejarah dan Pengantar Ilmu Al-Qur'an, Jakarta: Bulan Bintang, 1994. , Ilmu-Ilmu Al-qur'an: Media-Media Pokok Dalam Menafsirkan AlQur'an, Jakarta: Bulan Bintang, 1987.

Ațiyyah Aram, Muhammad Sa'īd Muhammad, al-Sabīl ila Ma'rifat al-Așil wa alDakhïl fi al-Tafsīr, Mesir: Zaqāziq, 1998.

Dimyathi, Afifudin, Ilmu Tafsir, ushulihi wa manhajihi, Sidoarjo: Lisan Arabi, 2016.

Fayāḍ, 'Abd al-Wahāb, Ad-Dakhil fi al-Tafsir Al-Qur'an Al-Karim, Mesir: Matba'ah Hasan, 1978.

Hadi, Abdul, Tasawuf yang Tertindas: Kajian Hermeneutika, Jakarta: Paramadina, 1992.

Hadna, Ahmad Mustafa, Problematika Menafsirkan Al-Qur'an, Semarang: Toha Putra, 1993.

Hambal, Ahmad bin, Musnad Ahmad bin Hambal, Beirūt: Mu'assasah al-Risālah, 1999.

Hasan, Abdul Halim, Tafsir Al-Ahkam, Jakarta: Kencana Prenada Media Group, 2006.

Ibn Kas̄īr, Abu al-Fidā' Ismā'̄̄l, Tafsīr Al-Qur'an Al-Aẓim, Beirūt: Dār alToyyibah, 1999.

Junaidi, Rofiq, “Al-Ashil wa Dakhil fi Tafsir” dalam Jurnal Al-A'raf, vol. XI, no. 2, Juli-Desember 2014

Juoro, Umar, Kebenaran Al-Qur'an dalam Sains: Persandingan Wahyu dan Teori Fisika tentang Alam Semesta, t.t. PT Pustaka Cidesindo, 2011.

Khalīfah, Ibrahīm 'Abd al-Raḥmān, al-Dakhīl fi al-Tafsīr, Kairo: Jāmi'a al-Azhar, tt.

Khon, Abdul Majid, Ulumul Hadist, Jakarta, Amzah, 2009.

Mukhaimir,Ali,al-Dakhîl fi al-Tafsir, Kairo: Jami'a al-Azhar, tt.

Munawwir, A. W., Kamus Al-Munawwir, Surabaya: Pustaka Progresif, 1997.

Mustaqim, Abdul, Madzahibut Tafsir, Peta Metodologi Penafsiran Al-Qur'an Periode Klasik Hingga Kontemporer, Yogyakarta: Nun Pustaka, 2003.

Muta'al, Isa Anshori, Dkk, Ulumul Hadits, Palembang, Raden Fatah Press, 2005. 
Shihab, M. Quraish, Kidah Tafsir: Syarat, Ketentuan, dan Aturan yang Patut Anda Ketahui dalam Memahami al-Qur'an, Tanggerang: Lentera Hati, 2013.

, Membumikan Al Qur'an: Fungsi dan Peran Wahyu dalam Kehidupan Masyarakat, Bandung: Mizan, 1999.

Suparta, Munzier,Ilmu Hadist, Jakarta: Rajawali Pers, 2010.

Ulinnuha, Muhammad, “Al-Ashil dan al-Dakhil Dalam Tafsir Al-Qur'an” dalam Jurnal Madania, vol. 21, no. 02 Desember 2017.

Usamah, Abu, Ilmu-Ilmu Hadits, Jakarta: Darul Ibn Hazm, 2007. 